\title{
The Development and Reference of Japanese Railway Culture
}

\author{
Cong-yi Jin $^{1 *} \&$ Zhong-wei Shen ${ }^{1}$ \\ ${ }^{1}$ School of architecture and design, Southwest Jiao Tong University, Chengdu, Sichuan Province, \\ China \\ *Cong-yi Jin, E-mail: 652246350@qq.com
}

Received: April 26, 2017

Accepted: May 3, 2017

Online Published: May 10, 2017

doi:10.22158/jecs.v1n2p93

URL: http://dx.doi.org/10.22158/jecs.v1n2p93

\begin{abstract}
Japanese railway culture has a long history, brilliant achievements, railway travel and the Japanese people's daily lives are closely related to the railway feelings in the hearts of the Japanese. The prosperity and development of Japanese railway culture is closely linked with the developed country's industry, stable social environment, enthusiastic public support, and extensive media publicity. By exploring the development process of railway culture in Japan, we can provide some references for the construction of railway culture in China.
\end{abstract}

Keywords

Japanese railway culture, development, reference

\section{Introduction}

Japan is a highly developed capitalist country, the country has a perfect modern transport system, the level of its railway development in the world. October 14, 1872, a total length of $29 \mathrm{~km}$ of the new bridge in Tokyo, Japan to Yokohama officially opened, opened the tortuous development of the Japanese railway and a long history, today, the scale of its construction has been all over the country. The railway and public life are closely linked, as the daily travel aboard, has been deeply imprinted in the Japanese memory, become a social symbol characteristic. With the developed railway industry, Japan Railway culture is unique, has a long history of the development of the industry to support the strong, powerful media, popular support Japan, which has become an important part of cultural industry, and the Japanese railway culture of the brilliant development, solid state and industry behind the developed industrial economy, healthy and stable social environment.

\section{Beginning}

Japan Railway Culture Development from the beginning of twentieth Century, early as government officials, royalty or businessman travel photography pictures, records the Japanese railway tedious and long construction process at the turn of the century, a precious collection review of the early history of 
Japan railway; After the Meiji Restoration, Japan embarked on the expansion of militarism Road, since 1930s, the railway transportation under military control, in addition to the image data recorded the Japanese imperialist aggression and expansion of the railway, folk photography and gathering activities is limited, the period of the development of railway culture is in the low stage.

\section{Development}

After the end of World War II, Japan to repair the wounds of war, the revitalization of the national economy, railway repair and construction work carried out gradually, the relevant business units to be restored, the Japanese railway cultural activities also ushered in the development of new opportunities. 1946 to Kanto, Kansai as the center of the two activities, people concerned and like the railway began to set up a community, and the issue of homemade publications, to expand the impact of railway culture activities. In 1947, Japanese fans the first railway magazine Railway model interest (Figure 1), The journal exquisite model railway photography and related activities to record, and report the real railway news and articles, the railway culture communication has expanded on the media platform, the influence of folk culture in the railway. In November 1953, Japan's first nationwide railway enthusiasts group, the friends of the railway will be set up, located in Kanda Transport Museum activities become railway enthusiasts gathered, gradually expand the scale of the impact of railway culture.

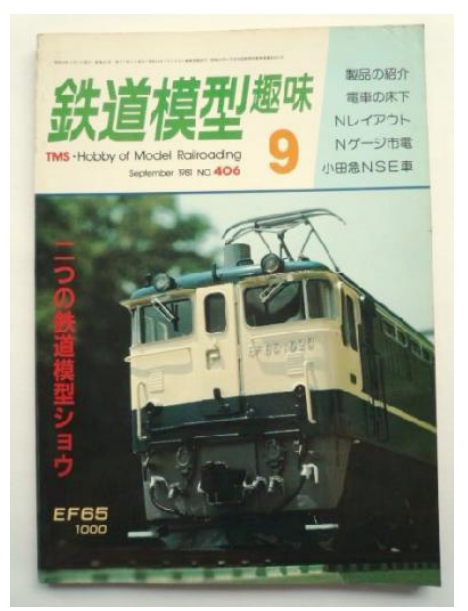

\section{Figure 1. Journal of Railway Model Interest}

Source: http://www.myday.cn/yahoo-n147946376.html

\section{Expansion}

In 1960s, the rapid development of the Japanese economy, the national railway construction has made brilliant achievements, in October 1, 1964, from the Tokyo Olympic Games 9 days before the opening of the world's first high-speed railway from Tokyo to Osaka, the new route opened (Figure 2), as a symbol of national strength and the development of science and technology of the railway enthusiasts in Japan under the glory, the glory of the moment in history the camera records, domestic and foreign 
news media have reported a continuous pursuit, expand the opening of the new line of international influence. During this period, the scale of the Japanese Railway Cultural enthusiasts to expand, a wide range of activities, the impact began to spread to the general public; at the same time, the retirement of the old train caused by the nostalgia of the people, by way of photographic records retained. Subsequently, with the advent of the information age of the Internet, so that the Japanese railway enthusiasts have a broader exchange platform, through social media to expand the impact of the railway enthusiasts groups gradually younger age, the trend of development. The manufacturing industry through powerful technology, the company continues to receive new railway trains, meet the needs of market development; at the same time, colorful painting, different types of trains continue to emerge, has become the foundation of Japanese railway culture. Japan Railway Company in the construction of a new line, pay attention to the promotion and open to the public, organize people to visit the experience of the new line of trial operation, especially for children, student groups set up to support the development of national railway construction concept, its good affinity, has created the huge Railway culture enthusiasts groups today. Japan, railway has become an indispensable transportation tool in people's life, the new route is the promotion of national name card, become a symbol of Japan's national strength.

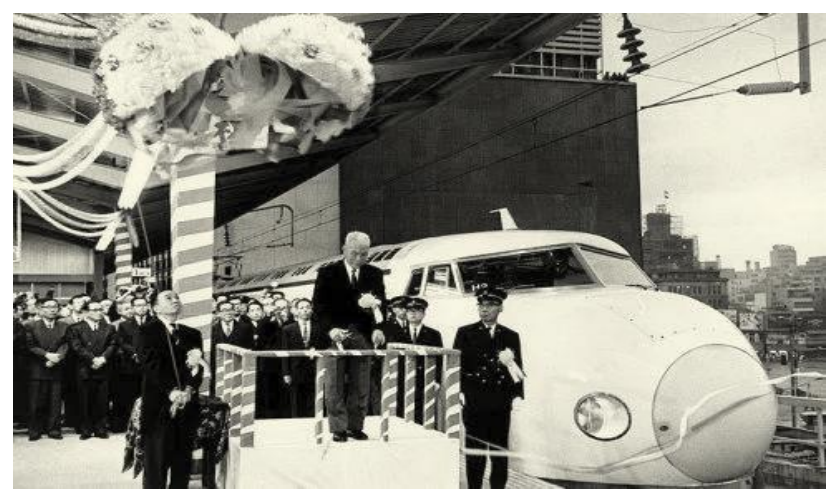

Figure 2. Opening Ceremony of the First Shinkansen in Japan in 1964

Source: http://www.360doc.com/content/17/0219/02/12109864_630190234.shtml

\section{Influence}

Japanese daily is one of the most transportation travel by train; at the same time, the railway transportation network extending in all directions and the domestic and foreign tourists to the country, bring high popularity and considerable benefits to the local, to promote regional economic development. With the development of regional tourism industry, the Japan Railway Company also launched a new route, including tourist train, theme painting train design beautiful for tourists to take pictures, provide delicious lunch for the passenger train, with souvenirs and brochures, in order to improve the line visibility, the development of local tourism economy (Figure 3). 


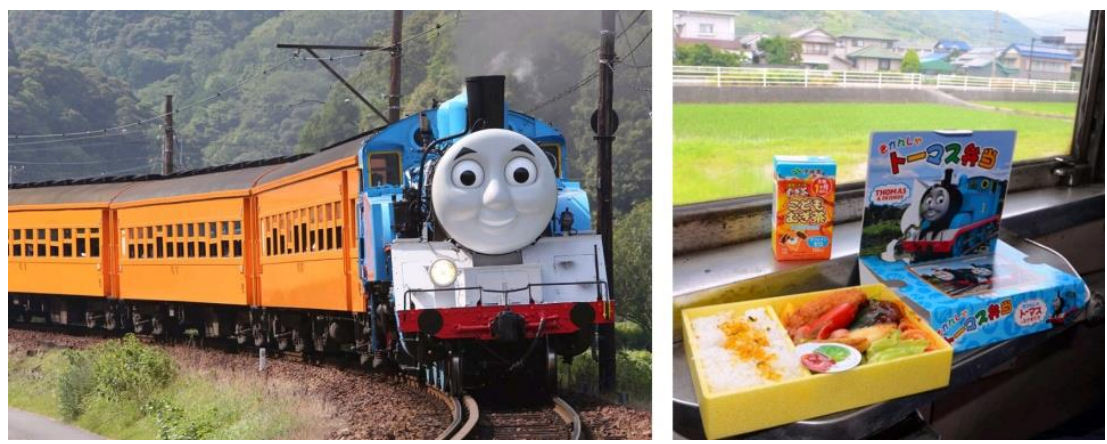

Figure 3. Japanese Tourist Train and Food

Source: http://www.roll.sohu.com/20140703/n401726380.shtml

In addition, ride on the train on the railway has become a Japanese writer, writer, poet, painter, journalist, object crew frequently involved in. In the related works: a moving train, shaking the handrail, change of sunshine, swaying platform, short broadcast, hurried crowd, blending emotion the content of the works. The melody composed of interwoven. For decades after the normalization of Sino Japanese relations, China has introduced a large number of Japanese literature, film, animation, games, one of the most profound impression on the audience Chinese, is hastily Benz in Mt Fuji, on the river, between the town of train; a picture from the train to build a picture of the scene in the flashing at present, make the audience feel the delicate and unique social life of Japan (Figure 4).

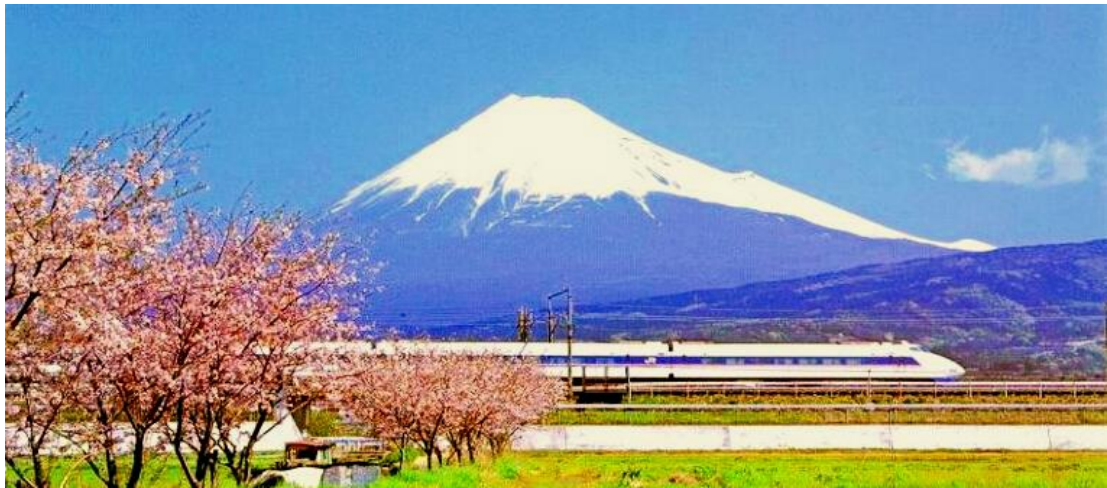

Figure 4. Mt Fuji and Shinkansen

Source: https://www.zhidao.baidu.com/question/489487523091771652.html

\section{Reference to China}

Similar to the Japanese railway, China railway has a long history, a tortuous course, brilliant achievements, with the development of railway Chinese overseas markets, the development and promotion of Chinese railway culture, has become an important way to develop modern China socialist cultural influence. It should be noted that the development of railway culture in the present Chinese society still has many limitations:

(1) China has a vast territory, the development of the difference of a larger area of railway construction, 
uneven density, the level of urbanization in some areas is not high, traffic inconvenience. The old station, dark platform, slow green cars, is the people of the common understanding of the railway, limited to the pure mode of transportation, the railway cultural understanding insufficiency, the lack of emotional identity.

(2) China and Japan city traffic patterns are different, the city traffic system mainly depends on the subway, bus, taxi as the city railway transport, use less traffic in the urban areas, for long distance delivery between the city. In addition to the holidays, ordinary people in daily life for the dependence of railway travel is not high, its influence understanding of railway culture.

(3) The construction of China's railway part of the city region is lagging behind, the lack of management on both sides of the line, for the city shantytowns and security and blind spots, dirty and closed environment along the line of estrangement, reduce people to the railway friendliness, needs improvement and management.

(4) The relevant departments of publicity for the railway culture, promotion of small, on line planning, construction, production and operation of the new type of train, foreign information new station building deficiencies, in terms of people still need to be improved; and the related domestic movie and TV literature less, not formed a complete industrial chain, to be public recognition and understanding. With the arrival of China's high-speed rail era, China set off a new round of the wave of railway construction, railway construction and development has become the focus of attention of ordinary people; on the one hand, the railway management departments to intensify propaganda and development of intelligent APP service website, WeChat, micro-blog and other social networking platform to interact with people, enhance friendly degree; on the other hand, in recent years the railway culture in the folk, the network platform is developing rapidly, the scale of railway enthusiasts and activities have gradually expanded; at the same time, many city held railway related exposition (Figure 5), the construction of the railway Museum (Figure 6), theme parks and leisure places, open to the public. Deepen the knowledge and understanding of the railway culture, promote the development of China railway culture.
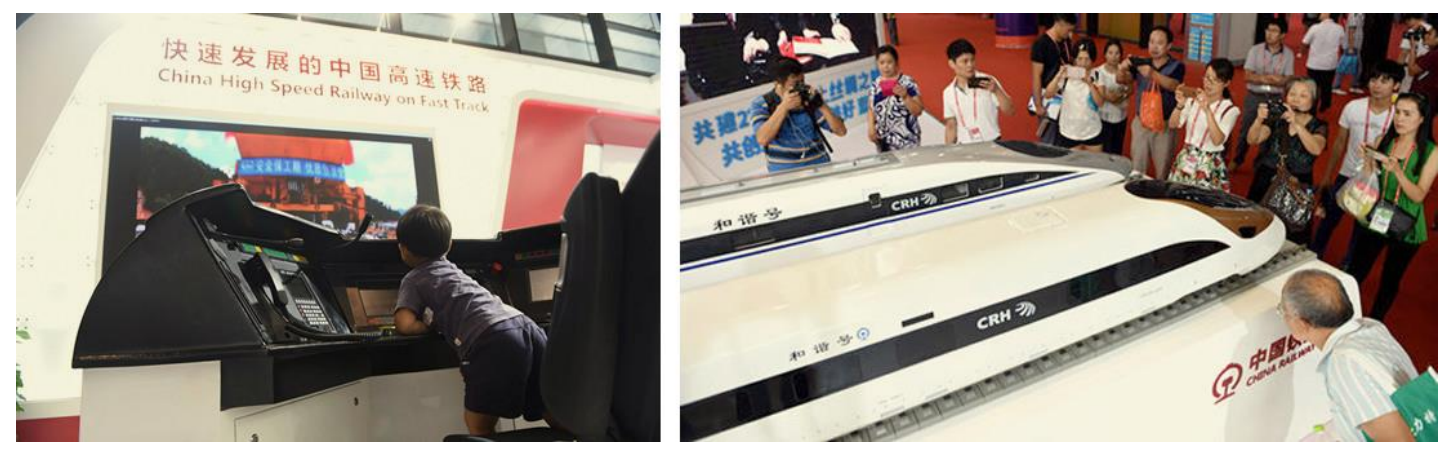

Figure 5. China's High Speed Railway in the Twelfth China-ASEAN Expo

Source: http://www.nanningjie.com/a/20150919/85300.html 

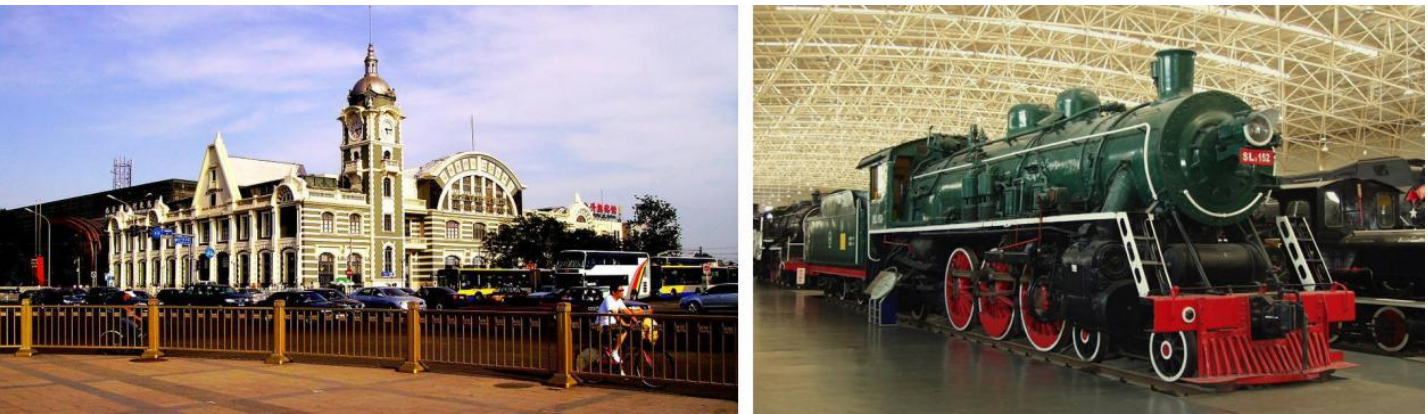

Figure 6. China Railway Museum and Steam Locomotive

Source: http://www.zijia.bitauto.com/place/t_852/

\section{Conclusion}

A long history and brilliant achievements, create a unique culture of Japan Railway, railway culture is the epitome of contemporary Japanese society, to build a daily life, carrying the tide of the times of ups and downs. The vigorous development of postwar Japan Railway Culture, embodies its prosperity from barren and show the courage to forge ahead, never yield in spite of reverses, the fighting spirit of innovation, become aware of another window of Japanese society and culture.

\section{References}

Wang, J. (2012). Japanese food culture characteristics. Journal of Dai zong, 2012(1), 31-32.

Zhang, T. (2004). Analysis of railway culture traceability and its management function. Journal of China Railway, 2004(6), 58-59.

Zuo, F. Q. (2012). Japan's Shinkansen high-speed railway development and cultural features. Journal of Forum of hundreds of academic thoughts, 2012(11), 37-39. 